\title{
BREVES APONTAMENTOS SOBRE A DIMENSÃO ESPACIAL DA CULTURA ${ }^{1}$
}

\author{
Patrícia Frangelli ${ }^{2}$
}

\section{Resumo}

A Geografia remete suas origens aos saberes desenvolvidos pelos gregos a fim de compreender a diversidade das atuações humanas e dos ambientes no mundo conhecido. Porém a sua sistematização enquanto ciência ocorreu no bojo das demais sistematizações ocorridas entre os séculos XVIII e XIX, em meio ao período histórico do positivismo de Augusto Comte, no qual as condições históricas, geográficas, culturais e epistemológicas eram propicias, senão sem escolha. No final daquele século (1890), descrever a diferenciação cultural foi destaque entre as ciências que tinham cunho político-social, influenciadas pelos estudos antropológicos, mas acima de tudo pelo imperialismo das potências ocidentais. Para a geografia cultural, independente dos traços tradicionais ou renovados, a cultura e sua manifestação no espaço sempre são primordiais. Assim o geógrafo busca a configuração que determinada prática cultural exprime no espaço. Em um primeiro momento, este artigo visa demonstrar como a geografia cultural vem se desenvolvendo, para logo em seguida trazer para pauta os novos rumos que vem seguindo.

Palavras-chave: Pensamento Geográfico; Geografia Cultural; Cultura; Paisagem Cultural.

\begin{abstract}
The Geography refers your origins to the knowledge developed by the Greeks to understand the diversity of human activities and environments in the world abroad. But your systematic while science occurred in the midst of other systematizations occurred between the eighteenth and nineteenth centuries, amidst the historical period of the positivism of August Comte, in which conditions historical, geographical, cultural and epistemological were favorable, but no choice. At the end of that century (1890), describe the cultural differences

\footnotetext{
${ }^{1}$ Este artigo faz parte de um trabalho maior desenvolvido na monografia de final de curso, intitulada: A Construção do Lugar de Memória (Lieu de Mémoire) em São Cristóvão: os Mitos no Solar da Marquesa. FRANGELLI, P. Monografia de final de curso, Universidade do Estado do Rio de Janeiro, Instituto de Geografia. Teses CTCC/UERJ, p.104. 2007.

${ }^{2}$ Mestranda do PPGEO/ UERJ, Bolsista Faperj, Ex-Bolsista NEPEC/ UERJ. E-mail: patfbl@yahoo.com.br
} 
were highlighted among the sciences that had political and social nature, influenced by anthropological studies, but above all by the imperialism of Western powers. To cultural geography, independent of traditional features or renewed, the culture and its manifestation in space is always paramount. Thus the geographer seeking a particular practice setting that expresses the cultural space. At first, this article aims to demonstrate how cultural geography has been developed, to then bring to staff the new direction that has followed.

Keywords: History of Geographic Thought; Cultural Geography; Culture; Cultural Landscape.

\begin{abstract}
$* * *$
Várias opiniões em relação à natureza da geografia ainda são comuns. $\mathrm{O}$ rótulo geografia, bem como o rótulo história, não é uma indicação confiável em relação ao conteúdo. Enquanto os geógrafos discordarem em relação ao seu objeto, será necessário, através de definições repetidas, procurar uma base comum sobre a qual uma posição geral possa ser estabelecida (SAUER, 2004, p. 12).
\end{abstract}

A pergunta que motiva os estudos em pensamento geográfico refere-se à natureza desta ciência. Ao percorrer essa trajetória verificamos que a simples e também completa definição em si mesma de Geografia como o estudo do espaço, por sua imensidão acaba por não definir muito. Devido a essa natureza extensa contida em si mesma é que nós geógrafos nos adequamos aos disseres acima de Sauer (2004) quando este afirma que a discordância existente sobre o objeto de estudo nos leva a sempre percorrer os caminhos daquilo que o define e reafirmá-lo sempre uma vez mais. Percebemos que corroborar com este raciocínio é também reviver e reafirmar um pouco da história do pensamento geográfico em nossos trabalhos. Seguindo esta lógica, para compreender a abordagem cultural necessita-se primariamente esmiuçar o conceito de cultura na antropologia, pois em termos desse conceito, a antropologia e a geografia são próximas.

\title{
Cultura da Antropologia à Geografia: breves apontamentos
}

A cultura em antropologia refere-se principalmente a origem e ao desenvolvimento do conceito, sendo este múltiplo em significados e norteador de seus estudos. Da mesma forma que o espaço está para a geografia, a cultura está para a antropologia. No final do século XIX, em meio a legitimação das ciências sociais através da metodologia das ciências naturais já 
consolidadas, Edward Tylor apud Laraia (1989), antropólogo americano, sintetizou cultura como o conjunto de conhecimentos, de costumes, de leis, de arte e de capacidades quaisquer adquiridos por um ser humano em comunidade. Isto significa que um único vocábulo sintetizava todas as atividades, ações e possibilidades das práticas humanas sobre a terra, independentemente de sua carga genética. Entretanto, para Tylor existiria uma unidade cultural na humanidade, negando os diversos caminhos possíveis de criação, transformação e absorção das inúmeras culturas (LARAIA, 1989).

Os ares epistemológicos sobre cultura começaram a se modificar com os estudos de Franz Boas (apud LARAIA, 1989) porque este ressaltava a importância das investigações históricas na investigação do conjunto sociocultural do objeto em estudo. E consagrou-se posteriormente com o antropólogo Alfred Kroeber (apud LARAIA, 1989), quando este rompe definitivamente com o determinismo biológico sobre as ações humanas no clássico artigo " $\mathrm{O}$ Superorgânico". Este antropólogo manteve a preocupação em bem definir até onde o equipamento biológico interferiria nas ações e criações humanas, pois por mais que este equipamento seja comum a todos os membros da humanidade, as culturas são diversas, variando não plenamente através do determinismo biológico e geográfico, mas como animal capacitado racionalmente para a criação de seu próprio destino. Neste sentido, o homem superou as questões orgânicas, possibilitando a povoação das mais remotas áreas do planeta. Mesmo revolucionário, nos perguntamos se a dialética homem-cultura, estaria presente nesta teoria. Estaria?

Mas do que a problemática da dialética, o conceito agora se tornava tão amplo e complexo que antropólogos como Clifford Geertz, Claude Levi-Strauss e David Schneider todos (apud LARAIA, 1989), se engajaram numa forma de operacionalizá-lo e transformá-lo em um instrumento menos amplo, todavia mais poderoso tecnicamente. O primeiro caminho foi marcar a origem do desenvolvimento da cultura remetendo-o a linha de congruência entre o desenvolvimento do equipamento biológico humano e o desenvolvimento da cultura, ou seja, comprovavam-se a simultaneidade do processo. Isto não apenas transformou a cultura em uma característica da espécie como o volume cerebral, mais também transformou o homem no produtor da cultura e não mais somente no produto da cultura. A partir desta comprovação, entender o conceito de cultura significava compreender a natureza humana. E assim, a antropologia moderna, nas proposições do sistematizador Roger Keesing citado por Laraia (1989), a fim de atingir essa meta talvez inatingível, fragmentou-se na especialização de áreas, porém alargou seu leque de estudos ao introduzir na antiga teoria dos sistemas adaptativos - teorias sobre a adaptabilidade humana às necessidades de sobrevivência, de 
desenvolvimento das técnicas e tecnologias e outros-, as teorias idealistas de cultura (LARAIA, 1989).

Essas teorias idealistas compreendem três estudos (LARAIA, 1989):

- O sistema cognitivo - consiste no estudo dos modelos desenvolvidos pelos membros da comunidade a respeito de seu próprio "mundo"; a maneira na qual um sistema de conhecimento é produzido, transmitido e aceito ou não por essa comunidade. A antropologia cognitiva vem se apropriando dos métodos de domínio da linguagem em seus tratados. Tal idéia é fortemente marcada na antropologia inglesa;

- O sistema estrutural - os antropólogos estruturalistas consideram a cultura como um sistema simbólico em que a estruturação dos diversos domínios da cultura (religião, crenças, genética, linguagem) possibilita o entendimento dos princípios mentais que geram, transformam e condicionam as elaborações culturais. Idéia destacada na antropologia francesa;

- O sistema simbólico - a cultura, para estes antropólogos, não significa um complexo de comportamentos concretos e sim um conjunto de mecanismos de controle do comportamento humano. Os significados dos modelos conscientes não estão apenas nas mentes das pessoas mais também nos objetos, símbolos e construções públicas e privadas. Logo estudar a cultura é estudar um código de símbolos partilhados pelos membros dessa cultura em estudo. Idéia trabalhada na antropologia americana.

E por que de considerar interessante abordar o conceito de cultura dos antropólogos se o nosso estudo é geográfico? Porque o conceito de cultura, sua aplicação em estudos empíricos ou teóricos, seu desenvolvimento e entendimento por pertencer à natureza humana interessa a todas as ciências e principalmente para aquelas de forte cunho social. Devido a isto, o conceito de cultura não é exclusivo da antropologia, e em perspectiva, a geografia de maneira interdisciplinar utiliza-se das discussões epistemológicas que vinham ocorrendo naquela disciplina para fundamentar suas proposições em geografia cultural.

\section{Geografia cultural tradicional e renovada}

A geografia remete suas origens aos saberes desenvolvidos pelos gregos a fim de compreender a diversidade das atuações humanas e dos ambientes no mundo conhecido (CLAVAL, 1999). Porém a sua sistematização quanto ciência ocorreu no bojo das demais sistematizações ocorridas entre os séculos XVIII e XIX, em meio ao período histórico do positivismo de Augusto Comte, no qual as condições históricas, geográficas, culturais e 
epistemológicas eram propicias senão sem escolha. No final deste mesmo século (1890), descrever a diferenciação cultural foi destaque entre as ciências que tinham cunho políticosocial, influenciadas pelos estudos antropológicos, mas acima de tudo pelo imperialismo das potências ocidentais.

Em um primeiro momento, essa geografia cultural impregnada de positivismo estudava os aspectos materiais das culturas (vestuários, regionalismos, técnicas, utensílios), ou analisando os modos de existência dos grupos humanos em seu gênero de vida de concepção vidalina, ou enfatizando as marcas deixadas pelos grupamentos humanos na paisagem natural, mas também a paisagem cultural, dando a perceber as interferências do homem que acabam por imprimir-se no espaço conferindo-lhe uma nova organização tão bem estudada por geógrafos alemães e norte-americanos. Porém, pós-guerras mundiais (1940), a intensificação da mundialização com o progresso das técnicas, lutas sociais e diversificação do cotidiano, estas abordagens perderam seu prestígio, pois descrever e relatar às culturas ignorando as representações, os signos, as crenças e subjetividades soava destoante com as tendências pós-modernas (CLAVAL, 1999).

Assim como naquele primeiro momento, a geografia cultural seguiu a mudança de paradigma, reconhecendo a insuficiência de seus princípios (CLAVAL, 1999) frente à complexidade das culturas cada vez mais alicerçadas em imaterialidades como: ideologias, sistemas de representação e valores - elementos nos quais o positivismo não consegue abarcar-. Em meados da década de 1970 surgem trabalhos nos quais tanto os aspectos materiais quanto os não-materiais começam realmente a ser abordados a ponto de ser possível identificar esta geografia como geografia cultural renovada (ROSENDAHL, 1999).

Mas, o que acarretou essa mudança de paradigma? Segundo Claval (1999) foi a "descoberta" ou o entendimento da variabilidade dos agrupamentos humanos no tempo e no espaço precisamente. Mais do que isso, o entendimento da natureza destes agrupamentos influenciado pela filosofia do materialismo histórico-dialético geográfico, como também as filosofias do significado valorizando o simbólico. A importância recai sobre a análise da construção dos indivíduos e suas subjetividades tanto a sua psicologia quanto a maneira de Focault em suas teorias sobre a individualidade na sociedade, e Deleuze sobre o esquizóide, fatores que a partir de interações ou da vida de relações projetam um novo olhar sobre os agrupamentos humanos e como se realizam na transferência de valores, técnicas, atitudes, idéias e outros. (CLAVAL, 1999)

A abordagem cultural em geografia, como sinalizado anteriormente, seguia a corrente praticada pela antropologia mais influente em sua área, por exemplo, a princípio a cultura 
tanto em geografia quanto na antropologia americanas era concebida como algo imposto, exterior ao indivíduo, uma espécie de realidade transcendente onde os indivíduos passivamente recebiam as influências sociais e culturais. Essa maneira de abordar a cultura como somente portadora de autonomia foi praticada pelos geógrafos culturais tradicionais e efetivamente desenvolvida por Carl Sauer (2004) e seus discípulos americanos (Escola de Berkeley). Foi um período relativamente longo, Claval (1999) situa esta corrente entre as guerras mundiais, seguindo de uma forma decadente até os anos de 1960.

Essa decadência está ligada a queda de inúmeros paradigmas. Um tempo em que antigas convicções se remodelaram e uma nova ordem se estabeleceu. As críticas ferrenhas a este modo de conceber a cultura não só partiram dos estudos antropológicos, pois a cultura é de interesse comum a todas as ciências de cunho social. Deste modo a percepção de que cultura em geografia no mundo globalizado e de relações deveria modificar-se, considerando não somente o savoir-faire e as práticas daquela antiga concepção, mais também as atitudes, as idéias, as questões mutáveis que cada indivíduo ou grupo interioriza, individualiza e aprimora ao longo da vida. Segundo Claval (1999, p.64) “a cultura não é uma realidade global: é um conjunto diversificado ao infinito e em constante evolução”. Um conceito de cultura mais flexível e complexo que coubesse a visão geográfica estava por ser moldado nas rodas dos debates científicos. Nessas rodas, a geografia cultural renovada começava a se estabelecer, impregnada pelas filosofias existencialistas, do significado, e pela geografia crítica e humanística.

Para a geografia cultural, a cultura e sua manifestação no espaço são primordiais. Assim o geógrafo busca a configuração que determinada prática cultural deixa no espaço. Para a geografia cultural renovada, essa configuração cultural circunda os indivíduos, é produto deles, produz experiências neles e é constante ao se considerar a sucessão de diversas manifestações culturais diferenciadas a cada fração de espaço e tempo. Sucessão esta multifacetada: multisensitivo - pois abrange todos os sentidos-, e desordenada - não segue uma direção linear nem no tempo, nem no espaço-, apesar de demarcada por uma historicidade (a "marca" da época), e por um espaço limitado quanto à capacidade de absorção de informações e destaque dado pelo observador.

Ao considerar o indivíduo como observador é importante ressaltar o binômio cultura e observador. O destaque dado ao observador ser um limitador, parece importante, e por isso deve-se frisar, pois na pós-modernidade o valor dado ao individual (individualismo) em detrimento do coletivo, ou da especificação a qual reduz-se o formigueiro à formiga, é uma visão muito valorizada em qualquer estudo teórico que se propõe compreender a lógica de 
produção e dos mecanismos de conhecimento. O observador é um limitador, após um longo tempo de observação e durante o decorrer do mesmo, ele busca identificar na experiência lembranças ou algo que torne aquilo decifrável ou cognoscível. O circundante lhe traz sensações muitas vezes novas, mas que o indivíduo não consegue absorver visto que busca aquilo que lhe é familiar, positivo ou negativamente. Isto ocorre devido à esfera de valores do indivíduo (esfera construída no tempo histórico e vivenciada no espaço em que se insere), essa que gera consistência, coerência e fixidez vista em seu conjunto, como um sistema de valores que dá significado a sua existência. Essa "solidez" gerada pela esfera de valores em sistema cria a falsa percepção de que o cotidiano é dominado e que o circundante não lhe traz o novo, porque "tudo" aquilo já foi experienciado, de alguma maneira já é natural - um mecanismo psicológico de proteção de seus valores-. Os processos de banalização da violência recaem sobre essa lógica do cotidiano: o novo se parece com o velho, de onde é possível identificar semelhanças com aquilo que de nada é semelhante, a não ser o fato de pertencer ao conjunto da violência.

Apesar da aparente contradição, a relação cultura-observador não é estabelecida em termos de constância, de permanência. Concordamos com Claval (1999) quando este define a construção desse relacionamento através da idéia de redes de contatos entre diversos indivíduos e o observador, considerando as inúmeras informações, em diferentes códigos de linguagem. Neste sentido, essa relação é dependente intra e intercomunicacionalmente, além de estar impregnado de inúmeras intersubjetividades. Essa intersubjetividade ainda varia segundo a etapa de vida dos indivíduos envolvidos - crianças, adolescentes, adultos-; gênero; escolhas de vida e técnicas empregadas na comunicação. Ainda mais complexa é a análise das subjetividades relacionadas ao conhecimento, a crença, a religião, a ideologia e outras categorias intelectuais que moldam o comportamento e o modo de ser de cada indivíduo. Cada um destes variando no espaço-tempo e paradoxalmente tornando-se mais próximos com a globalização.

Após tantas direções as quais tentamos demonstrar a complexidade do ser humano ante as suas produções e sobre o qual estas influenciam em sua criatividade, observamos que o conceito de cultura tornou-se praticamente inoperante - é grande demais-. Assim, elaboramos o quadro abaixo, mais sucinto que o discorrer apresentado acima, a partir da enumeração proposta por Claval $(1999$, p.67) sobre os três componentes da cultura a fim de elucidar alguns dos diversos caminhos da análise do conceito: 
(...) cultura tem a ver com a composição da bagagem de representações, de savoirfaire, de destreza, de conhecimentos, de atitudes e de princípios que cada um se constrói. [grifo nosso]

\section{Quadro 1: Componentes da Cultura}

\begin{tabular}{|c|c|}
\hline $\begin{array}{c}\text { Conhecimentos, Técnicas, Savoir-Faire } \\
\text { ambientais }\end{array}$ & $\begin{array}{l}\text { Abrangem tudo o que permite a cada um se } \\
\text { localizar no mundo, de reconhecer nele } \\
\text { ambientes ricos e ambientes pobres, ambientes } \\
\text { estáveis e ambientes inseguros, e de colocar } \\
\text { em ação os meios indispensáveis para se } \\
\text { deslocar, se proteger, se nutrir e constituir um } \\
\text { arsenal de utensílios e de máquinas que } \\
\text { explicitam as realidades que nos envolvem. }\end{array}$ \\
\hline Conhecimentos, Técnicas, Savoir-Faire sociais & $\begin{array}{l}\text { Oferecem a cada um a possibilidade de } \\
\text { encontrar seu lugar no universo social no qual } \\
\text { se insere, de utilizar os códigos de } \\
\text { comunicação que nele estão em ação, e de } \\
\text { compreender quais as formas de arquitetura } \\
\text { social que nele funcionam. }\end{array}$ \\
\hline Objetivos, esfera de valores & $\begin{array}{l}\text { Para agir, não é suficiente compreender o } \\
\text { mundo e a sociedade, é necessário estabelecer } \\
\text { objetivos. O terceiro componente da cultura } \\
\text { repousa, portanto, sobre as perspectivas com as } \\
\text { quais os homens se dotam para comparar o } \\
\text { mundo, tal como ele é, com aquilo que ele } \\
\text { poderia ser e deveria ser para orientar sua ação } \\
\text { e para dar um sentido à sua existência. A esfera } \\
\text { de valores tem igualmente como função } \\
\text { integrar os dois outros e definir, em seu seio, } \\
\text { as opções ambientais ou sociais apreciadas, e } \\
\text { outras que parecem mais nefastas ou } \\
\text { condenáveis. }\end{array}$ \\
\hline
\end{tabular}

Fonte: CLAVAL,P. A geografia cultural: o estado da arte. IN: ROSENDAHL, Z. e CORREA, R. L. Manifestações da cultura no espaço. Rio de Janeiro. EdUERJ. 1999, esquematizado por FRANGELLI, P.

Com este quadro é possível perceber que a abordagem cultural na geografia difere sensivelmente daquela abordada pela antropologia, ressaltada a interdisciplinaridade na qual a geografia se mesclou a fim de desenvolver as suas próprias especificidades. Obviamente percebe-se que não há uma revelação e assim um novo campo de pesquisa geográfica. O que ela exprime é uma nova maneira de olhar e legitimar-se. Compreendendo a ligação ou comunicação existentes entre a cultura, o homem e seus respectivos aparatos em constante congruência (e não em paralelismo), a nova abordagem cultural desta forma empregada na geografia, inclui em sua análise aquelas abstrações e "invisibilidades" aos quais os geógrafos não se perguntavam, ou não se permitiam perguntar, devido ao momento histórico que pertenciam ou a falta de conceitualização sólida que os

[ajudasse] a compreender como os homens e as sociedades se fazem e se desfazem em um movimento perpétuo que criou o individual a partir do coletivo, e o coletivo 
a partir das ações individuais.(...) A Geografia (...) de ontem estudava a organização do espaço como o resultado da ação de parcela da população que trabalhava e produzia. Hoje, os geógrafos têm interesse em todas as formas de percepção dos lugares, de construção do outro e de fixação da fronteira entre nós e os estrangeiros.(CLAVAL, 1999, p.94)

Após estas considerações a cerca do conceito de cultura e da abordagem cultural na geografia, faz-se necessário realizar a seguinte pergunta demarcatória: como traduzir esta complexidade em conceitos geográficos? Diversos geógrafos culturais trabalham cultura nos cinco conceitos-chave geográficos: espaço, lugar, território, região e paisagem. De modo a elucidar o que vem sendo dito, nos propomos a trazer a paisagem para discussão.

\section{A paisagem cultural como um exemplo de análise do espaço}

Estudar as paisagens era foco da geografia cultural tradicional tanto americana quanto alemã, do início da sistematização da ciência até meados do século XX. Seus esforços se concentravam na caracterização da natureza do lócus em estudo, ou seja, na vegetação, na geomorfologia, na hidrogeografia, na fauna, nos modelos das construções, nas formas bucólicas no campo e agrárias em geral, enfim, nas formas contidas na paisagem em estudo (CLAVAL, 1999). A pesquisa se dava em uma espécie de inventariado, no levantamento das informações contidas na área em estudo e descritas minuciosamente quanto ao seu uso e utilidades. Seu foco estava nas sociedades pré-modernas e nas rugosidades que poderiam ser encontradas ainda numa porção da Terra, uma certa "arqueologia" geográfica, ou nas comunidades pré-capitalistas, como tribos e agrupamentos humanos que fugissem a lógica econômica daquele período, um "serviço" ao imperialismo das grandes potências, ou uma forma de compreender o presente a partir de sociedades consideradas em um nível evolutivo inferior - como dizia algumas correntes científicas daquela época-. Carl Sauer (2004) em seu clássico artigo sobre a geografia cultural legitima esse estudo de inventário como aquele capaz de realizar um dos objetivos gerais da geografia: o objetivo de diferenciar e compreender o planeta em áreas. Para Sauer (2004, p.14) a paisagem seria:

(...) o equivalente em inglês para o termo que os geógrafos alemães estão usando amplamente, e tem estritamente o mesmo significado: uma forma da Terra na qual o processo de modelagem não é de modo algum imaginado como simplesmente físico. Ela pode ser, portanto, definida com uma área composta por uma associação distinta de formas, ao mesmo tempo físicas e culturais.

A fim de atingir esses planos e ao mesmo tempo manter-se como uma ciência objetiva 
da Terra, a paisagem era compreendida como uma verdadeira fotografia: "tudo" que os olhos pudessem abarcar objetivamente deveria ser catalogado. Em perspectiva observamos que os estudos geográficos relativos à paisagem privilegiavam e continuam ainda privilegiando o sentido da visão e isto se deve muito pela facilidade de estruturar as noções de distância, das escalas e sobre-planos a partir deste órgão dos sentidos. Cabe ainda ressaltar que os olhos como parte integrante do pesquisador participa ativamente sobre "o ponto de vista" ou "do olhar" do mesmo - por mais redundante que seja a própria expressão empregada-, designa o sentido da visão como aquele que determina a forma de abordar o tema pelo pesquisador. $\mathrm{E}$ este como um ser composto de subjetividades não pode se auto-titular neutro. Aquilo que dedicamos e ao desviamos o olhar pertence à esfera de valores que aceitamos, recusamos, negligenciamos ou ignoramos, sejam eles no campo da ética, da estética, da política, e outros.

A partir da década de 1970, assim como ocorreu a toda geografia cultural tradicional, o conceito de paisagem transformou-se, adquirindo mais do que a realidade objetiva captava. Isso não significa que essas "antigas" maneiras de desvendar a paisagem foram abolidas, descartadas completamente dos estudos geográficos (CLAVAL, 1999). Significa que perderam seu foco de destaque, se antes elas eram o objeto do estudo agora complementam a análise a cerca das representações simbólicas, estas que hoje ganham terreno perante a complexidade da era pós-moderna. Podemos dizer que a partir dos estudos elaborados pós1970 a respeito do conceito de paisagem que o foco de análise recai sobre as representações simbólicas, os processos culturais que a envolvem e os valores embutidos nela.

Nas representações simbólicas ocorrem um outro tipo de comunicação, a comunicação simbólica. Quando usa-se o termo comunicação queremos destacar a ocorrência de algum tipo de troca, afinal comunicação requer de alguma maneira um emissor da mensagem e pelo menos um receptor. Este emissor pode ser uma coisa, um ser humano ou algo imaterial, mas qualquer que seja a natureza substancial ou não substancial, isto está em relação a algo ou em potencialidade de vir-à-ser para algo. Então observamos que existe uma transferência de informação, um compartilhamento, uma troca. O termo comunicação simbólica engloba em si mesmo esta compreensão. Para Claval (1999) esta natureza intrínseca não é o detalhe primordial, e sim a idéia por trás desta comunicação, isto é, a idéia de contato, de aproximar indivíduos que se sentem semelhantes, antagônicos ou diferentes por compartilharem ou não dos mesmos valores transmitidos pelo símbolo: 
indivíduos instalados em lugares distantes sentirem-se solidários a partir do momento em que experimentam o sentimento de ter em comum as mesmas crenças (Gottmann, 1952); o contrário, ela distancia aqueles que, mesmo geograficamente próximos, aderem a religiões ou a ideologias diferentes. A geografia cultural mostra, portanto, que os grupos humanos participam de um duplo sistema de distâncias: a do espaço físico, que as técnicas permitem controlar mais ou menos bem; as dos espaços psicológicos, que cavam fossos entre os sistemas culturais, ou os preenchem, independentemente das distâncias físicas. (CLAVAL, 1999, p.71)

Para o autor supracitado esse duplo sistema de distâncias na verdade não é tão antagônico como pressuporíamos a princípio, muitas vezes é o olhar do pesquisador, instrumento pouco neutro, que torna esse sistema de distâncias um abismo desmesurável.

Deste modo, a paisagem interpretada a partir dos processos culturais, dos valores e principalmente das representações simbólicas, passa a ser adjetivada por paisagem cultural. Desta forma grifada e utilizada, o pesquisador deseja demonstrar que esse espaço especial de análise desempenha em cada indivíduo uma troca dialética de conhecimento e de informações. Ao mesmo tempo em que ela instrui sobre a maneira que se deve orientar segundo o status quo ou o grupo que a construiu ou a repele, ou seja, retrata parte da sociedade na qual esta inserida com as trocas da vida de relações e do homem-meio ambiente; ela descortina o observador que a olha revelando-o em sua própria análise. Desta maneira a paisagem jamais é estática, pois cada observador é um indivíduo singular e potencialmente capaz de remodelá-la. E é sobre isso que nos fala Augustin Berque (2004).

Um grande salto qualitativo tanto na melhor definição quanto no entendimento deste conceito-chave de paisagem foi dado por Augustin Berque (2004) ao aprimorar a questão da manifestação concreta, anteriormente tratada analiticamente na concepção positivista, mas que Berque (2004) alerta para a relação desta com o sujeito coletivo, devido à dialética no qual a sociedade é responsável por sua produção, como também reprodução e posterior superação - no sentido de vir algo além-. É este processo vivo de passividade, atividade e potencialidade, o que determina a sua plurimodalidade. $\mathrm{O}$ interesse da geografia cultural na paisagem estaria em observar e definir a lógica deste processo.

Obviamente, este mesmo autor alerta para a insuficiência de definir somente essa relação sociedade-paisagem, pois faz-se urgir o entendimento a partir de duas vias: a primeira do observador e a segunda da co-integração. Os observadores por que ao possuírem uma consciência individual no self, e coletiva como pertencente à comunidade (necessariamente presente ou não na paisagem estudada), ao qual se apropriam da experiência gerada por essa, então a internalizando e passando a uma cognição a cerca da mesma, a partir daquilo que consideram ou não, seja qual for a esfera - estética, ética, política, social-, possuem um 
entendimento particular da relação. Porém isto se dá porque é a paisagem quem gera esse turbilhão de experiências e expectativas. Vê-se que o processo é totalmente concomitante e continuo em sua dialética de construção, emissor e receptor de percepções, e transformação. Por exemplo, uma exposição de arte induz a pensamentos primários sobre a arte exposta falamos primariamente porque supomos que o observador observe primeiro os elementos da paisagem, mas isto não descartaria a possibilidade do observador não as perceber e sentir a paisagem através de uma experiência sua sobre qualquer outra coisa-, mas seja o que for isto, foi provocado pelo contato com a paisagem, paisagem essa produzida por alguém (cultural), emissora de uma informação, capaz de receber também informações e transformar a ambos. Assim geograficamente percebe-se que a paisagem e o sujeito observador são co-integrados, criando uma simbiose naquele processo de produção, reprodução e superação.

Sobre isso poderiamos citar Meinig (1996), quando este sugere como um grupo de pessoas poderia observar a mesma cena sobre ângulos variados. Sua preocupação não se foca nos elementos contidos na paisagem estudada, mas na maneira singular que cada observador olha a mesma cena, destacando aquilo que lhe parece mais interessante, e mais ainda, o pesquisador está interessado na maneira que estes observadores irão descrever ou destacar os elementos considerados relevantes. A preocupação do pesquisador então recai sobre a essência das idéias que estes olhares constroem seus discursos a cerca da paisagem estudada. Seu destaque está na cognicibilidade desta comunicação.

Retornando, a partir de suas observações, Berque (2004) desenvolve os conceitos de paisagem-marca, aquilo que o observador percebe; o lócus privilegiado onde as atividades humanas deixam o seu registro, e paisagem-matriz, aquilo que determina o olhar, o lócus privilegiado onde a reunião destes registros cria sentido, refletindo uma mensagem cognoscível sobre a sociedade, o ambiente, o homem, etc. Esta maneira revolucionária de compreender a paisagem possibilitou que não apenas áreas formais do planeta sejam estudadas, mais também pinturas, textos literários, letras de músicas e outros objetos iconográficos passem a compor a narrativa das paisagens culturais pelo fato concreto de representarem manifestações simbólicas culturais.

A paisagem cultural realmente ganhou outro impulso com os estudos de Berque e a formalização dos conceitos de paisagem-marca e paisagem-matriz. Aproximadamente no mesmo período, outro geógrafo, porém agora inglês e proveniente das influências de outra linha antropológica, trouxe a cena da geografia cultural conceitos da escola crítica em geografia quanto à relação de poder existente nas formas simbólicas espaciais. A paisagem poderia assumir a forma de denúncia das relações contraditórias vigentes no espaço, como 
também esclarecer a forma com que isto se organizaria no mesmo. Representante desta corrente, Cosgrove (2004) "denunciaria" este estado das coisas ao conceitualizar as paisagens como dominantes e alternativas.

A paisagem para Cosgrove (2004) é uma unidade visual na qual o geógrafo exprime uma determinada forma de ver o mundo. Essa expressão segundo o geógrafo inglês teria surgido no Renascimento (por volta do século XV) e indicaria aquilo que os atores sociais daquela época, principalmente os pintores e artistas de modo geral, relatavam como uma harmoniosa, coerente, racional e ordenada relação homem-ambiente. Desta maneira o seu próprio vocábulo manteria uma estreita ligação com essa forma de observar o mundo, estando ao mesmo tempo acessíveis a mente e orientando as ações junto ao ambiente - já é possível observar nesta maneira de conceituar a paisagem, uma preocupação em entender esse controle frente à natureza e as forças que transformam o mundo, ou seja, a cultura como explicada tópicos acima-. Combatendo uma visão ainda presente cotidianamente, mas não mais formalmente presente nos trabalhos científicos, Cosgrove (2004) faz referencia a tradição antiga inglesa de considerar a cultura como práticas particulares a um agrupamento humano, aquilo que identifica, a identidade deste agrupamento, apreendidas, compartilhadas e transmitidas de geração a geração. Esta continuidade, senso de círculo, alienaria os membros desse agrupamento de modo que essas práticas culturais estariam muito pouco conscientizadas - esse processo é denominado determinismo cultural-. Essa teoria realmente poderia fazer algum sentido em comunidades e agrupamentos humanos pré-capitalistas, mas, e quanto às sociedades contemporâneas e pós-modernas?

A atual concepção de cultura como multidimensional, oferecendo diferentes possibilidades de percepção simultaneamente e sem hierarquização em suas validações, rechaça esta continuidade alienante pertencente à lógica do determinismo cultural, idéia esta de que a cultura agiria acima dos seres humanos. Apesar de reconhecermos que existe uma espécie de círculo, todavia de outra natureza, no qual a cultura precisa ser constantemente produzida, reproduzida e transformada pelos seres humanos, ou seja, necessita de um ritual que a "reviva", muitas vezes repleta de ações inconscientes ou reflexivas que pertencem desde rotinas cotidianas a celebrações suntuosas em tempos e espaços específicos. Nas palavras de Cosgrove (2004, p.102-3)

(...) a cultura é, ao mesmo tempo, determinada por e determinante da consciência e das práticas humanas.(...) O tomate, um objeto natural, é tirado do pé, é cortado e apresentado como alimento humano. O objeto natural tornou-se objeto cultural, foilhe atribuído um significado. O significado cultural é introduzido no objeto e também pode ligá-lo a outros objetos aparentemente não relacionados a ele na 
natureza. Dizer que o tomate é um produto cultural não significa que suas propriedades naturais estejam perdidas. Sua cor e peso estão inalterados, uma análise clínica produziria os mesmos resultados antes ou depois do evento cultural. Mas foram acrescentados a estas propriedades atributos culturais que podemos identificar e discutir.

Esta fácil ilustração realizada por Cosgrove a fim de demonstrar a ordinariedade da cultura nos prepara para perceber uma natureza um pouco menos perceptível da cultura e por isso mesmo mais ardilosa: a ligação entre cultura e poder. $\mathrm{O}$ estudo desta relação requer a compreensão da vida de relação do lócus estudado, desde um arcabouço histórico que lhe permita perceber os atores sociais e chamadas elites atuantes, como a construção e organização espacial da área em estudo. Um grupo dominante, como o próprio léxico afirma, é identificado como o grupo que exerce algum tipo de poder sobre os demais, esse grupo tenderá manter ou impor sua perspectiva e ótica cultural - proposições, modelo de vida, normas-, aos demais grupos pertencentes a sua comunidade. Muitas vezes essa ótica cultural ou identidade de grupo, está tão impregnada na comunidade que a ligação cultura e poder é quase imperceptível aos membros dos demais grupos - este fenômeno é denominado hegemonia cultural e podemos identificá-lo em diversas escalas, das familiares às mundiais-. Desta maneira identificamos nas paisagens culturas dominantes e subdominantes (ou alternativas), como pares indissociáveis que apresentam sempre alguma expressão na paisagem, podendo ser analisadas em diferentes termos: de gênero, política e etc. Sendo as culturas subdominantes divididas em: residuais - em termos históricos propriamente relativos ao passado-; emergentes - que sofrem algum tipo de emersão frente às culturas dominantes-, e excluídas - que sofrem algum tipo de supressão frente a demais culturas apresentadas-. (COSGROVE, 2004)

Elaboramos, o quadro ilustrativo a seguir, na tentativa de privilegiar as idéias do geógrafo inglês Denis Cosgrove (2004): 
Quadro 2: Paisagens Culturais de Cosgrove

\begin{tabular}{|c|c|c|c|}
\hline Paisagens culturais & Definição & Subdivisões & Definição \\
\hline Dominantes & $\begin{array}{l}\text { Por definição, cultura dominante é a de um } \\
\text { grupo com poder sobre outros. [O significado } \\
\text { da ideologia dominante consiste em manter e } \\
\text { reproduzir seu poder]*, até um ponto } \\
\text { consideravelmente importante, por sua } \\
\text { capacidade de projetar e comunicar, por } \\
\text { quaisquer meios disponíveis e através de } \\
\text { todos os outros níveis e divisões sociais, uma } \\
\text { imagem do mundo consoante com sua própria } \\
\text { experiência, [sendo muitas vezes]* essa } \\
\text { imagem aceita como reflexo verdadeiro da } \\
\text { realidade de cada um. }\end{array}$ & & \\
\hline \multirow{3}{*}{$\begin{array}{l}\text { Subdominantes } \\
\text { ou Alternativas }\end{array}$} & \multirow{3}{*}{$\begin{array}{l}\text { [Cultura subdominante é a de um grupo que } \\
\text { por motivos vários, vê-se concorrente, mas } \\
\text { subposta, a uma cultura de um grupo } \\
\text { percebida como dominante.]* } \\
\text { Se define nas próprias subdivisões. }\end{array}$} & $\begin{array}{c}\text { Paisagens } \\
\text { Subdominantes } \\
\text { Residuais }\end{array}$ & $\begin{array}{l}\text { São elementos da paisagem que pouco têm de seu significado } \\
\text { original. Alguns podem ser desprovidos de qualquer significado. } \\
\text { Geralmente são usando como pistas para a reconstrução de antigas } \\
\text { geografias. [são marcas de um passado histórico da paisagem.] }\end{array}$ \\
\hline & & $\begin{array}{c}\text { Paisagens } \\
\text { Subdominantes } \\
\text { Emergentes }\end{array}$ & $\begin{array}{l}\text { São de muitos tipos e muitas vezes transitórias e com impacto } \\
\text { relativamente pequeno sobre a paisagem. Está na natureza de uma } \\
\text { cultura alternativa oferecer um desafio à cultura dominante } \\
\text { existente, trazendo uma visão de futuros alternativos possíveis. }\end{array}$ \\
\hline & & $\begin{array}{c}\text { Paisagens } \\
\text { Subdominantes } \\
\text { Excluídas }\end{array}$ & $\begin{array}{l}\text { São paisagens de grupos culturais marginais que de algum modo } \\
\text { vem sendo suprimidas pelos demais grupos. As paisagens humanas } \\
\text { estão repletas de símbolos de grupos excluídos que tentam } \\
\text { sobreviver junto aos significados mais "atrativos" dos demais } \\
\text { grupos. }\end{array}$ \\
\hline
\end{tabular}

Fonte: COSGROVE, D. A geografia está em toda parte: cultura e simbolismo nas paisagens humanas. IN: ROSENDAHL, Z. e CORRÊA, R.L. (org) Paisagem, Tempo e

Cultura. EdUERJ. 2a ed. 2004. Esquematizado: FRANGELLI, P.

*imersão nossa. 
Novamente é preciso compreender que para interpretar essas impressões e expressões da cultura na paisagem, faz-se necessário o conhecimento do código ou linguagem empregada pelos grupos culturais, ou seja, os símbolos e seus significados contidos nesta paisagem, pois todas possuem uma dimensão simbólica com o propósito de estabelecer os valores, reproduzir as normas e etc. dos grupos culturais que inseriram aquele elemento naquela paisagem, assim como são re-experimentados a cada novo contato e revividos a cada nova ritualização, reexame e decodificação, permitindo "refletir sobre nossos próprios papéis para reproduzir a cultura e a geografia humana de nosso mundo diário" (COSGROVE, 2004, p.116), mesmo que os insiders e os outsiders não possam compreendê-lo pela falta de alguma cognocibilidade a respeito da natureza e do uso dos símbolos. "É tarefa que pode ser realizada por qualquer pessoa no nível de sofisticação apropriado para elas. Porque a geografia está em toda parte, reproduzida diariamente por cada um de nós” (COSGROVE, 2004, p.121).

Deste modo observa-se que a paisagem transcende os objetivos materiais que se propõe para trazer a tona um significado peculiar ao mundo exterior e interior do indivíduo. Um significado simbólico inseparável da vida de relações da sociedade no tempo e no espaço, o qual se estabelece através da troca constante entre as mais diversas unidades culturais (indivíduos, grupos, comunidades) e o seu próprio meio. A dimensão simbólica da paisagem, portanto, está sujeita as mais diversas interpretações e representações. Cosgrove (2004) designa a paisagem como uma imagem cultural porque em constante movimento determinado pelas forças componentes das paisagens da cultura dominante e subdominante. Este embate pode assumir as mais diferentes formas de representação: um texto literário, uma música, uma pintura e outras formas iconográficas. Porém, à medida que os estudos da paisagem “desvelam" essas representações ou as interpretam, mais um novo significado é transferido a essa paisagem em estudo, assim acumulando cada vez mais significados tendendo ao infinito do quanto ela existir - verificamos a dialética da relação paisagem-homem que destacamos nos estudos de Berque (2004)-. As fontes ou tipos de evidência "documentais", abrangindo a idéia de produto cultural, como os textos literários, a música, a pintura e outros, podem fornecer bases legítimas sobre os significados contidos na paisagem e seus conflitos, entretanto, devem ser examinadas adequadamente segundo técnicas apropriadas e respeitados o contexto histórico-espacial que foram criadas.

\section{Conclusão}


Do apresentado ao longo do artigo, percebemos que a cultura não está acima, ao lado ou não está atrelada somente ao homem pelo homem, e muito menos representa uma realidade primeira, visto que é uma construção imaginada geradora de comunicação e de unidades (grupamentos humanos: grupos, comunidades). A paisagem cultural assimilando as características do conceito de cultura também é uma imagem, um construto não no sentido simples de refletir como uma imagem no espelho, mas de ser reflexivo como o espelho. Claval (1999) expressa este conteúdo ao definir “O papel do geógrafo não é explicar o homem, a sociedade, a cultura, o espaço, mas se interrogar sobre as razões que levam os homens a construírem sistemas simbólicos que negam a distância, ou a exaltam" (CLAVAL, 1999, p.73). A abordagem cultural na geografia raciocina em termos geográficos de: áreas, fronteiras, localizações e distâncias; estes que são os elementos da organização espacial dos agrupamentos humanos (diferentemente das conotações puramente geométricas que associam a geografia à formulação de mapas, e dados puramente materiais e visíveis). Corroboramos a idéia de que a geografia não poderá imergir profundamente nos fenômenos da natureza humana, caso continue atrelada a idéia de "uma história natural do mundo e de suas divisões regionais". (CLAVAL, 1999, p.79)

Ao possuir uma condição de instabilidade, de flexibilidade muito complexas a respeito das diversas significações e representações que uma porção de espaço pode assumir, verificamos que a paisagem cultural além destas propriedades acima, também possui uma idéia de corte do espaço-tempo (uma idéia de momento, de pausa ligeira, mas acima de tudo de continuidade do processo). Desta maneira possibilita a comunhão entre a complexidade da cultura e a organização dos espaços humanos. E à medida que se incrementam as pesquisas em geografia cultural, a paisagem vem sendo considerada o conceito-chave da geografia aquele conceito que legitima os estudos da ciência geográfica dando a ela o status independente e pleno de realização. Porém, pelo menos por enquanto, as controvérsias existentes possibilitam que os estudos sejam ricos e avançados.

\section{Referências Bibliográficas}

BERQUE, A. Paisagem-Marca, Paisagem-Matriz: Elementos da problemática para uma Geografia Cultural. IN: ROSENDAHL, Z. e CORREAA, R.L. (org) Paisagem, Tempo e Cultura. EdUERJ. $2^{\mathrm{a}}$ ed. 2004.

CLAVAL, P. A geografia cultural: o estado da arte. IN: ROSENDAHL, Z. e CORREAA, R. L. 
Manifestações da cultura no espaço. Rio de Janeiro. EdUERJ. 1999

COSGROVE, D. A geografia está em toda parte: cultura e simbolismo nas paisagens humanas. CORREAA, R.L.; ROSENDAHL, Z. (orgs) IN: Paisagem, Tempo e Cultura. EdUERJ. $2^{\mathrm{a} e d .} 2004$.

LARAIA, R. de B. Cultura: um conceito antropológico. Rio de Janeiro. Jorge Zahar Editor. $5^{\mathrm{a} e d .} 1989$.

MEINIG, D. W. O olho que observa: dez versões da mesma cena. Revista Espaço e Cultura. $n^{\circ} 13.1996$.

ROSENDAHL, Z. Apresentação. IN: ROSENDAHL, Z. e CORRÊA, R. L. Manifestações da cultura no espaço. Rio de Janeiro. EdUERJ. 1999

SAUER, C. O. A morfologia da paisagem. CORRÊA, R.L.; ROSENDAHL, Z. (orgs) IN:

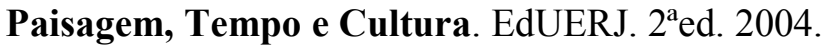

